\title{
Metaplasia in the Stomach-Precursor of Gastric Cancer?
}

\author{
Hiroto Kinoshita, Yoku Hayakawa * (D) and Kazuhiko Koike \\ Graduate School of Medicine, Department of Gastroenterology, The University of Tokyo, 7-3-1, Hongo, \\ Bunkyo-ku, Tokyo 113-8655, Japan; kinoshita-tky@umin.ac.jp (H.K.); kkoike-tky@umin.ac.jp (K.K.) \\ * Correspondence: yhayakawa-tky@umin.ac.jp
}

Received: 1 September 2017; Accepted: 25 September 2017; Published: 27 September 2017

\begin{abstract}
Despite a significant decrease in the incidence of gastric cancer in Western countries over the past century, gastric cancer is still one of the leading causes of cancer-related deaths worldwide. Most human gastric cancers develop after long-term Helicobacter pylori infection via the Correa pathway: the progression is from gastritis, atrophy, intestinal metaplasia, dysplasia, to cancer. However, it remains unclear whether metaplasia is a direct precursor of gastric cancer or merely a marker of high cancer risk. Here, we review human studies on the relationship between metaplasia and cancer in the stomach, data from mouse models of metaplasia regarding the mechanism of metaplasia development, and the cellular responses induced by H. pylori infection.
\end{abstract}

Keywords: gastric cancer; intestinal metaplasia; Spasmolytic polypeptide expressing metaplasia (SPEM); Helicobacter pylori; stem cells; lineage tracing

\section{Human Gastric Cancer Pathogenesis}

Gastric cancer was the leading cause of cancer-related death in the United States and other Western countries until the 1930s-1940s. Despite a significant decrease in the incidence of gastric cancer in Western countries over the past century, gastric cancer is still one of the leading causes of cancer-related death worldwide [1]. Most human gastric cancers arise after long-term Helicobacter pylori infection via a multi-step histopathological cascade known as the Correa pathway, which involves the following steps: gastritis, atrophy, intestinal metaplasia (IM), dysplasia, and ultimately cancer [2-4]. Metaplasia is the replacement of one differentiated cell type with another mature differentiated cell type that is not normally present in a specific tissue [5]. IM in the stomach is histologically defined as changes in gland structure (to resemble intestinal glands) and the presence of intestine-specific lineage cells that are not present in the normal stomach such as goblet cells and Paneth cells. IM in the stomach is molecularly characterized by expression of intestine-specific transcription factors of the caudal type homeobox (Cdx) family, CDX1 and CDX2.

During H. pylori infection, gastric atrophy, histologically defined as the loss of both chief and parietal cells, progresses from the antrum to the corpus along the lesser curvature, unless autoimmune gastritis is also present [6,7]. The histological extent of atrophy, as well as the endoscopic grade, is related to the risk of gastric cancer development [7-13]. As conventional endoscopy is not very accurate when used to diagnose IM (the sensitivity and specificity of endoscopic diagnosis of IM based on histology were about $25 \%$ and $90 \%$ [14]), histological analysis of multiple biopsy specimens is usually required to define the IM grade. Several studies have shown that IM is associated with a higher risk of cancer in the corpus than in the antrum alone (hazard ratios were 3.6 in the patients with IM in the antrum only and 3.8 for those with IM in the corpus), suggesting that IM progresses together with atrophy and predicts the gastric cancer risk $[7,13,15]$. Although $H$. pylori eradication to prevent cancer has been attempted in recent years [16,17], patients with high-level atrophy and 
IM are thought to be at especially high risk of gastric cancer even after $H$. pylori eradication $[15,18]$. Several recent studies have shown that IM may not improve after such eradication, suggesting that IM is irreversible [19,20], although other studies reported that eradication somewhat reduced the extent of IM [21-23]. Further prospective studies are needed to fully elucidate whether $H$. pylori eradication enables recovery from atrophy and IM, and eventually prevention for cancer development.

IM can be divided into two subtypes, complete and incomplete IM (Table 1). Complete IM resembles small intestinal glands with loss of gastric mucins (MUC1, MUC5AC, and MUC6) as well as the presence of eosinophilic enterocytes with brush borders, well-defined goblet cells, and occasional Paneth cells. In contrast, incomplete IM (also known as gastric or mixed type IM) resembles colonic glands in terms of structure, with multiple, irregular intracytoplasmic mucin droplets and absence of a brush border, and it often expresses gastric and intestinal mucins simultaneously [24]. Both types of IM express acid mucins (which contain substantial amounts of sialic acid and/or sulfate residues), which can be detected by Alcian blue staining at $\mathrm{pH}$ 2.5. In addition, incomplete IM expresses sulfomucins (which contain predominantly sulfate residues), which are stained brown by high iron diamine (HID), whereas complete IM expresses sialomucins (which contain predominantly sialic acid residues), which are not detected by HID staining [25]. One study found that incomplete IM was more proliferative than complete IM [26].

Table 1. Characteristics of metaplastic lesions in the human stomach.

\begin{tabular}{ccc}
\hline Type of Metaplasia & Histological Characteristics & Representative Markers \\
\hline Intestinal metaplasia (IM) & $\begin{array}{c}\text { Intestine-like gland structures } \\
\text { Intestine-specific cell lineages }\end{array}$ & $\begin{array}{c}\text { CDX1, CDX2 } \\
\text { MUC2, TFF3, Villin } \\
\text { Alcian blue staining at pH 2.5 }\end{array}$ \\
\hline Complete IM & $\begin{array}{c}\text { Small intestinal phenotype } \\
\text { Enterocytes with brush borders } \\
\text { Well-defined goblet cells } \\
\text { Paneth cells }\end{array}$ & $\begin{array}{c}\text { Loss of gastric mucins } \\
\text { (MUC1, 5AC, 6) }\end{array}$ \\
Incomplete IM & $\begin{array}{c}\text { Colonic gland-like structures } \\
\text { Irregular mucin droplets }\end{array}$ & $\begin{array}{c}\text { Brown staining by high iron } \\
\text { diamine (HID) }\end{array}$ \\
& $\begin{array}{c}\text { Both gastric and intestinal mucins } \\
\text { may be present }\end{array}$ \\
\hline Spasmolytic polypeptide- & $\begin{array}{c}\text { Deep antral gland-like structure } \\
\text { Expansion of a mucous neck } \\
\text { cell-like lineage }\end{array}$ & $\begin{array}{c}\text { TFF2, MUC6, GSII } \\
\text { expressing metaplasia (SPEM) }\end{array}$ \\
\hline
\end{tabular}

CDX1: caudal type homeobox 1; CDX2: caudal type homeobox 2; GSII: Griffonia simplicifolia lectin II; TFF2: trefoil factor 2; TFF3: trefoil factor 3.

Although earlier researchers proposed that gastric cancer arises from "intestinalized" glands in the stomach, it remains unclear whether IM is a direct precursor of gastric cancer or merely a marker of high cancer risk. Given that most metaplastic cells are non-proliferative and post-mitotic, complete IM (in particular) likely represents a differentiated cell lineage distinct from dysplasia or cancer. In fact, complete IM is merely a weak risk factor for gastric cancer, and it may even suppress cancer development $[27,28]$. The expression of CDX2 is also associated with better outcome in gastric cancer patients [29]. In contrast, incomplete IM appears to be a more significant risk factor for gastric cancer $[27,28,30,31]$. The incidence of incomplete IM is correlated with the extent of total IM. Thus, incomplete IM is considered to be a more advanced stage of IM among the multiple steps of carcinogenesis. However, it remains to be elucidated whether complete IM progresses directly to incomplete IM, or whether both types of IM emerge independently.

Several reports on the clonalities of human gastric specimens have revealed that both IM and dysplastic glands are clonal and can form large clonal patches via gland fission [32]. This process (termed "field cancerization") suggests that both dysplasia and metaplasia in the stomach originate 
from gastric stem cells. Somatic mutations commonly seen in gastric cancer, such as tumor protein p53 (TP53) mutation, can be found in non-dysplastic IM, which may argue in favor of IM leading directly to dysplasia and cancer [33,34]. In fact, the aforementioned study revealed that the same somatic mutations of TP53 or adenomatous polyposis coli (APC) were found in both IM and dysplasia in some of the cases [32]. The cellular kinetic changes evident in IM, in which the apoptotic index is significantly attenuated, (but the proliferation index is similar, to that of the non-IM epithelium), may also favor neoplasm formation [35]. However, it remains unclear whether IM glands can directly transform into dysplastic glands, or whether they simply share a common stem cell origin. In any case, it is important to unravel the molecular mechanisms of metaplasia development to develop effective approaches to cancer prevention and treatment.

\section{Mouse Models of Metaplasia}

To date, several murine models of metaplasia in the stomach have been developed [36]. Here, we briefly review these models and the insights they have provided into the molecular mechanisms and cellular origins of metaplastic lesions (Table 2).

Table 2. Characteristics of mouse models of stomach metaplasia.

\begin{tabular}{|c|c|c|}
\hline Type of Metaplasia & Histological Characteristics & Representative Markers \\
\hline $\begin{array}{l}\text { SPEM in Helicobacter infection or } \\
\text { after transgenic activation of } \\
\text { Ras-MAPK signaling }\end{array}$ & $\begin{array}{l}\text { Accompanied by atrophy, foveolar } \\
\text { hyperplasia, and inflammation } \\
\text { Dysplasia at later time points } \\
\text { No development of IM } \\
\text { Generally irreversible }\end{array}$ & $\begin{array}{l}\text { TFF2, MUC6, GSII } \\
\text { CD } 44 \mathrm{v} 9, \text { SOX9 } \\
\text { Alcian blue staining at } \mathrm{pH} 2.5\end{array}$ \\
\hline $\begin{array}{l}\text { IM in transgenic } \mathrm{Cdx} 1 / 2 \\
\text { mouse models }\end{array}$ & $\begin{array}{l}\text { Complete IM } \\
\text { Enterocytes with brush borders } \\
\text { Well-defined goblet cells } \\
\text { Paneth cells } \\
\text { Irreversible }\end{array}$ & $\begin{array}{l}\text { CDX1 or CDX2 } \\
\text { MUC2, TFF3 } \\
\text { Alcian blue staining at pH } 2.5 \\
\text { Brown staining by HID }\end{array}$ \\
\hline $\begin{array}{l}\text { Acute drug-induced injury } \\
\text { (DMP-777, L-635, high-dose } \\
\text { tamoxifen) }\end{array}$ & $\begin{array}{l}\text { Acute loss of parietal cells and } \\
\text { mature chief cells with } \\
\text { inflammatory infiltration } \\
\text { Reversible after discontinuation of } \\
\text { drug treatment }\end{array}$ & $\begin{array}{l}\text { TFF2, MUC6, GSII } \\
\text { Low expression of gastric } \\
\text { intrinsic factor } \\
\text { CD44v9 (DMP-777 and L-635) }\end{array}$ \\
\hline
\end{tabular}

CD44v9: CD44 variant 9; CDX1: caudal type homeobox 1; CDX2: caudal type homeobox 2; GSII: Griffonia simplicifolia lectin II; SOX9: sex determining region Y-box 9; TFF2: trefoil factor 2; TFF3: trefoil factor 3.

Metaplasia in the stomach in mice was first seen in a model of long-term Helicobacter felis infection, which triggers chronic inflammation, atrophy, and mucous-producing metaplasia [37-39]. The development of such histological changes in the proximal stomach was accelerated in insulin-gastrin (INS-GAS) mice, which exhibit higher levels of serum amidated gastrin $[38,40]$. Interestingly, gastrin protects against Helicobacter-induced carcinogenesis in the distal stomach antrum, suggesting that gastrin has different functions in the corpus versus antrum [41-43]. The anti-tumorigenic effect of gastrin is thought to be caused in part by suppression of the epigenetic silencing of Tff1, which encodes a tumor suppressor that attenuates nuclear factor kappa B (NF-KB) signaling [44,45]. Certain H. pylori strains, particularly the PMSS1 strain, which has a functional cag pathogenicity island (PAI), can also trigger atrophic gastritis and metaplasia [46-48]. In these models of Helicobacter infection, the development of host immune and inflammatory responses is the key to the induction of atrophic and metaplastic changes. For example, infection of T-cell-deficient mice with $H$. felis created no detectable gastric pathology despite high levels of colonization [39]. However, in Myd88-deficient mice, in which immunological tolerance is impaired, the gastric pathology was accelerated in response to H. felis [49,50]. Obesity, which causes low-grade systemic inflammation, exacerbated the gastric pathology induced by H. felis by enhancing the Th17 
response [51]. Mice infected with PMSS1 during the neonatal period were protected from gastritis, atrophy, and metaplasia by immunological tolerance [47]. Furthermore, inflammatory responses and metaplastic changes were attenuated under germ-free conditions [52], suggesting a role for commensal gastric microflora in disease progression.

On the other hand, several cytokines appear to be essential in the development of metaplasia. Overexpression of interlukin (IL)-1 $\beta$ in the gastric epithelium caused gastric inflammation, atrophy, metaplasia, and even development of invasive lesions (at later time points) [53], whereas IL-1 receptor-knockout mice were protected from the pathological process induced by H. pylori PMSS1 [48]. Transgenic expression of IFN- $\gamma$, SDF-1, or IL-8 in mice accelerated gastric inflammation and metaplasia during Helicobacter infection, via different mechanisms [54-56]. IL-33 triggered a Th2 response and metaplastic changes in the stomach when administered systemically [57].

However, the metaplastic lesions in these mouse models do not express $\mathrm{Cdx}$ family proteins and do not contain goblet cells or other intestine-specific cell types. Thus, metaplasia in most mouse models appears to differ from IM in humans. Rather, the mouse lesions express trefoil factor 2 (TFF2, also known as spasmolytic polypeptide), and the lesion is thus termed spasmolytic polypeptide-expressing metaplasia (SPEM) [37]. SPEM expresses other neck cell markers such as MUC6 and GSII and shows strong positive Alcian blue staining because of abundant mucins in the cytoplasm. Histologically, SPEM of the Helicobacter infection models can be divided into two subtypes: mucous metaplasia and pseudopyloric metaplasia [58]. Although these two lesions are morphologically distinct, both express similar neck cell markers and contain mucin-rich cells that exhibit Alcian blue positivity; both can thus be termed SPEM. However, given the expression of TFF2 and other markers in normal neck cells, any diagnosis of SPEM needs to be performed quite carefully. Alcian blue staining must be combined with analysis of recently discovered SPEM-specific markers such as CD44 variants and Sox9 when diagnosing genuine metaplasia [48,59].

Similar SPEM lesions have been reported in inflamed human stomachs by immunohistochemical analysis of TFF2 [60,61] (Table 1). It should be noted that SPEM glands in both human and mouse stomachs are similar in many aspects, but they need to be sharply distinguished from IM since their morphology and expressed markers are quite different. Analyses of resected human gastric corpus specimens revealed regions containing compound glands in which SPEM cells were observed in the deeper regions of the glands and IM lineages in the luminal portions of the glands, suggesting that IM may develop from the more proliferative SPEM [61], or that IM and SPEM share a common origin in such glands. In any case, whether SPEM in the human stomach has any relevance to gastric cancer remains unclear. Interestingly, Tff2-knockout mice were particularly susceptible to gastric inflammation and cancer, and TFF2 expression decreased during gastric carcinogenesis because of methylation of the TFF2 gene promoter, suggesting that TFF2 or SPEM may act as a tumor suppressor [58,62].

No mouse model has yet been reported to exhibit complete IM with goblet cells, except for transgenic mouse lines expressing $C d x 1$ or $C d x 2$ in the gastric epithelium [63-65]. Interestingly, $\mathrm{Cd} 2$ transgenic mice develop gastric adenocarcinoma at 100 weeks of age, suggesting that aberrant $\mathrm{Cdx} 2$ expression may induce malignant transformation in the stomach [66]. In contrast, several mouse models with epidermal growth factor receptor (EGFR)-Ras-mitogen activated protein kinase (MAPK) pathway activation in the gastric epithelium exhibited rapid development of SPEM-like metaplasia. Mutant Kras transgenic mouse lines have been widely used; mutant Kras is driven by various constitutive or inducible promoters such as K19 (constitutive), K19-CreERT, Ubc9-CreERT, Mist1-CreERT, Tff1-CreERT, eR1-CreERT, and Lgr5-CreERT [67-74]. These mice display rapid atrophy development, foveolar hyperplasia, and SPEM exhibiting positive Alcian blue staining and positive TFF2, GSII lectin, and CD44v9, but mostly negative Cdx1/2 immunostaining. Mutant Braf expression under the control of an inducible Tff1 promoter and overexpression of the EGFR ligand TGF $\alpha$ also triggered similar phenotypes $[72,75,76]$. Interestingly, mice deficient in amphiregulin, another EGFR ligand, developed SPEM and dysplasia at later time points [77], although the mechanisms of this seemingly counterintuitive result are not fully understood. Inhibition of the MAPK pathway 
prevented and reversed Kras-induced metaplasia, suggesting the potential utility of such inhibitors for treatment of metaplasia [71]. The bone morphogenetic protein (BMP) pathway [78,79] may play a role in metaplasia development via Smad phosphorylation, perhaps acting cooperatively with MAPK activation [80,81].

Other groups have developed short-term drug-induced metaplasia models using DMP-777, L-635, and high-dose tamoxifen [82-85]. The metaplastic lesions of these models express the neck cell marker TFF2 and low level of murine chief cell markers (e.g., intrinsic factor), but the expression of these markers is rapidly reversible after discontinuation of drug treatment. Acute recruitment of macrophages and production of inflammatory cytokines may play roles in the observed responses [86,87]. Although these models are useful for exploring the processes of acute injury and regeneration because of the relatively short time courses of the experiments compared with those performed in other transgenic or infection models, the reversible nature of the lesions contradicts the notion that metaplasia is caused by irreversible reprogramming of cell differentiation. Indeed, the short-term metaplastic lesions induced by high-dose tamoxifen do not exhibit markers of long-term SPEM, such as Alcian blue staining and CD44v9/Sox9 positivity, although recent reports have shown that CD44v9 expression was somewhat elevated after DMP-777 or L-635 treatment $[87,88]$. Parietal cell loss was initially believed to be the main trigger of metaplastic development in these models, but this has been questioned by a recent study showing that parietal cell loss alone did not induce metaplasia [85]. In our opinion, the mechanisms of drug-induced SPEM are essentially regenerative, thus reflecting responses to acute injury, leading to hyperplasia of neck/chief cell lineages.

Recently, Menheniott et al. reported that mice deficient in gastrokine-2, a secreted protein normally expressed by gastric surface mucous cells, spontaneously developed Alcian blue-positive mucous metaplasia and mucous neck cell hyperplasia and exhibited an exacerbated pathology when infected with H. pylori [89]. Together with the anti-tumorigenic effect of TFF1, which is also secreted by surface mucous cells, these results suggest that such cells play protective roles against gastric disease [45].

\section{Origins of Metaplasia}

As mentioned above, the field cancerization phenomenon suggests that both human IM and dysplasia are of stem cell origin [32]. Immunohistochemical analyses of SPEM/IM compound glands in the human stomach revealed that Ki67-positive proliferating cells are located mainly in the IM component which constitutes the upper half of the gland, suggesting that IM originates from the stem cell zone at the isthmus, not at the bottom, of the gland [61].

In mouse models, the origin of metaplasia in the stomach has been much debated. Given the abundant proliferation evident in the isthmus of the stem cell zone, metaplasia is thought to originate from isthmal stem or progenitor cells [59,90,91]. However, several groups have recently proposed a model whereby metaplasia originates from mature gastric chief cells through transdifferentiation [92,93]. Lineage tracing experiments using CreERT-expressing lines crossed to Rosa 26 reporter lines were used to analyze the origin of metaplasia, but the results were quite complex. Initially, Mist1-CreERT mice were used as a chief cell-specific line; metaplasia in these mice develops from Mist1+ cells [71]. However, later, our group revealed that not only chief cells but also isthmal stem cells express Mist1-CreERT [70]. Another group reported metaplasia development in eR1-CreERT mice crossed to mutant Kras mice, but both chief cells and isthmus stem cell/progenitor cells broadly expressed eR1-CreERT [73]. Lgr5 may be expressed more specifically in basal chief cells, and it has been reported that $L g r 5+$ chief cells do not give rise to metaplasia in Lgr5-CreERT-IRES-EGFP mice [94]. In addition, Mist1-CreERT crossed to LSL-Kras ${ }^{\mathrm{G} 12 \mathrm{D}}$ mice developed metaplasia even after $\mathrm{Lgr} 5+$ cell ablation in Lgr5-DTR mice [70]. Although these data strongly suggest that Lgr $5+$ chief cells are not the precursor to metaplasia, a group in Singapore recently reported that $L g r 5+$ chief cells can give rise to metaplasia after acute injury in a separate Lgr5-CreERT mouse line [74].

Several factors may influence the results and conclusions drawn in lineage tracing experiments. Tamoxifen used to activate the CreERT recombination can itself trigger acute injury of the gastric 
epithelium [84]. Genes of interest are often haploinsufficient after insertion of CreERT sequences that may affect cellular kinetics [70,95]. The frequency and efficiency of recombination varies depending on the Rosa26 reporter lines used in various experiments [96]. More specific Cre drivers or Cre-independent recombination models might be useful to avoid such influences, but we emphasize at this point that detailed careful observation is critical to obtain more accurate interpretations and conclusions. Analysis at various time points (particularly earlier time points), using different doses of tamoxifen, and examination of multiple sections or reconstructed 3D images, is essential to determine the exact cell fates in various models.

\section{Cellular Responses during H. pylori Infection}

Many studies on bacterial virulence factors and the host cellular responses to H. pylori infection have appeared [97-102]. Interactions between virulence factors and epithelial cells deregulate or activate various signaling pathways such as those involving NF- $K B$ and Ras-MAPK kinases. Many studies on the cellular responses to $H$. pylori infection were based on in vitro experiments using gastric cell lines. The effects of signaling pathway dysregulation in gastric epithelial cells have also been investigated in vivo, using mouse models such as those discussed above. Recently, a gastric organoid system has been used to investigate the interactions between H. pylori and epithelial cells [103].

One of the most important and best-studied virulence factors is the cytotoxin-associated gene A (CagA) and the associated type IV secretion system (T4SS), which are associated with various gastric pathologies including gastritis, gastric ulcers, and cancer [104,105]. These genes are located within the cag PAI, a 40-kb DNA segment containing a cluster of 30 genes [106]. CagA is delivered to the gastric epithelial cell cytoplasm via T4SS and then undergoes phosphorylation of the EPIYA motifs by host Src-family kinases [107-110]. Phosphorylated CagA binds to and activates the SH2-domain-containing protein tyrosine phosphatase (SHP2) [111]. CagA-activated SHP2, in turn, activates the Ras-MAPK pathway, which is involved in cell proliferation and perhaps the development of metaplasia [112,113]. Transgenic mouse models have been used to show that systemic expression of CagA triggers spontaneous development of gastric tumors, and that the tumorigenic effect of CagA is dependent on EPIYA motif phosphorylation [114]. EGFR, an upstream of the Ras-MAPK pathway, is also activated by $H$. pylori [115]. Basu et al. reported that the H. pylori secreted protein HP0175 activates EGFR via interaction with TLR4. The importance of EGFR activation in vivo was shown in mouse and Mongolian gerbil models [116]. These studies revealed the potential therapeutic implications of EGFR inhibition in patients with $H$. pylori gastritis.

CagA exerts a wide range of effects on gastric epithelial cells. One example is Wnt/ $\beta$-catenin pathway activation, which is particularly important for the development of colorectal neoplasia [117]. CagA activates the Wnt/ $\beta$-catenin pathway via interaction with E-cadherin, independent of tyrosine phosphorylation status. Wnt signaling can affect the expression of $C d x 1$, which was reported to be a Wnt target gene, and may be associated with IM development in the stomach [118]. In mouse models, however, Wnt signaling activation alone was not sufficient to induce $\mathrm{Cdx}$ expression or metaplastic changes in the corpus epithelium, as discussed above [70]. CagA was also involved in activation of the signal transducer and activator of the transcription 3 (STAT3) pathway $[119,120]$. The IL-6/STAT3 pathway was shown to play a role in gastric carcinogenesis in mouse models [121]. Other effects of CagA on gastric epithelial cells include cytoskeletal reorganization, increased proliferation and mobility, junctional defects, and polarity loss [122-124]. However, it remains unclear whether CagA is indispensable for gastric pathology, or whether other components of the cag PAI play more important roles. Importantly, H. pylori with the cag PAI also activates non-classical, stress-induced MAPK pathways, including those involving the JNK and p38 MAPKs. Upstream molecules of these pathways (including MAP3Ks such as transforming growth factor beta-activated kinase 1 [TAK1] and apoptosis signal-regulating kinase 1 [ASK1]) have been identified [121,125]. In mouse models, knockout of c-Jun N-terminal kinase 1 (JNK1) or ASK1 suppressed gastric tumorigenesis, likely via regulation of apoptotic responses and cyclin D1/E2F1-dependent cell cycle signaling [126-128]. H. pylori-derived 
lipopolysaccharide is another virulence factor involved in the activation of stress-induced MAPK pathways and subsequent apoptosis [129].

The NF- $\mathrm{KB}$ pathway, which regulates the expression of a wide variety of inflammatory cytokines, is another critical pathway involved in Helicobacter-induced gastritis and metaplasia [130,131]. Many in vitro studies have shown that CagA and/or the cag PAI activates the NF- $\mathrm{KB}$ pathway, triggering IL-8 or IL-32 upregulation and anti-apoptotic responses [132-135]. Interestingly, H. pylori-induced IL-8 upregulation is in part mediated by RhoA [136], which was recently reported to be frequently mutated in a subset of human gastric cancers [137-140]. Various mechanisms are involved in cag PAI-dependent NF-KB activation [125,141-143]. The toll like receptor (TLR) pathways, which are stimulated by bacterial lipopolysaccharide, trigger NF- $\mathrm{KB}$ activation in either a cag PAI-dependent or -independent manner [144,145]. Bacterial peptidoglycan can be delivered to gastric epithelial cells via T4SS, where it activates NF- $\mathrm{kB}$ via Nod1 [146]. Although it has been reported that NF- $\mathrm{KB}$ signaling in gastric epithelial cells may protect against $H$. felis-induced gastritis and the subsequent development of dysplasia [147], our group has suggested that NF-KB activation in gastric epithelial cells promotes gastric carcinogenesis via IL- $1 \alpha$ production in a chemically induced mouse tumor model [148]. Chronic inflammation, mediated principally by NF- $\mathrm{KB}$ signaling, promoted DNA methylation in gastric epithelial cells via activation of DNA methyltransferase 1 [149,150]. Although aberrant DNA methylation may be involved in the reprogramming of epithelial differentiation and metaplastic changes, no clear evidence supporting this idea has yet been presented.

\section{Conclusions}

As discussed above, recent lineage tracing experiments in mouse models and clonality analyses of human samples together suggest that tissue-resident stem cells likely give rise to both metaplasia and cancer, although other possibilities (such as cancer originating from bone-marrow-derived cells) have been suggested [151]. Ras-MAPK pathway activation, which is a direct effect of $H$. pylori infection (particularly by cag PAI-positive strains) of gastric epithelial cells, appears to be key in terms of long-term metaplasia, similar to what is seen in mouse models of Helicobacter infection and mouse models of transgenic activation of Kras.

However, IM in humans with gastritis is quite stable and almost irreversible, even after H. pylori eradication and subsidence of inflammation. One explanation for this stability is genetic and/or epigenetic reprogramming in stem cells, which may result in generation and maintenance of metaplastic glands.

An alternative hypothesis is that niche factors supporting tissue-resident stem cells and regulating epithelial differentiation are altered after long-term inflammation to activate MAPK pathways in stem cells or deregulate epithelial differentiation. Such niche factors potentially include immune cells, vascular endothelial cells [70], nerves [152-154], and fibroblasts, some of which may be derived from bone marrow [155]. Studies on such factors are needed to gain a deeper understanding of gastric pathophysiology and to develop useful clinical treatments in the future.

Acknowledgments: This work was supported by the KAKENHI Grants-in Aid for Scientific Research (Hiroto Kinoshita, 17K15927 and Yoku Hayakawa, 16H06749 and 17H05081), the Project for Cancer Research And Therapeutic Evolution (P-CREATE) from the Japan Agency of Medical Research and Development, AMED, the Mochida Memorial Foundation for Medical and Pharmacological Research, the Takeda Science Foundation Visionary Research Grant, the Mitsubishi Foundation, Natural Sciences, and the Advanced Research and Development Programs for Medical Innovation (PRIME) (Yoku Hayakawa).

Conflicts of Interest: The authors declare no conflict of interest.

\section{References}

1. Ferlay, J.; Soerjomataram, I.; Dikshit, R.; Eser, S.; Mathers, C.; Rebelo, M.; Parkin, D.M.; Forman, D.; Bray, F. Cancer incidence and mortality worldwide: Sources, methods and major patterns in globocan 2012. Int. J. Cancer 2015, 136, E359-E386. [CrossRef] [PubMed] 
2. Uemura, N.; Okamoto, S.; Yamamoto, S.; Matsumura, N.; Yamaguchi, S.; Yamakido, M.; Taniyama, K.; Sasaki, N.; Schlemper, R.J. Helicobacter pylori infection and the development of gastric cancer. N. Engl. J. Med. 2001, 345, 784-789. [CrossRef] [PubMed]

3. Correa, P.; Shiao, Y.H. Phenotypic and genotypic events in gastric carcinogenesis. Cancer Res. 1994, 54, 1941s-1943s. [PubMed]

4. Correa, P. Human gastric carcinogenesis: A multistep and multifactorial process-First american cancer society award lecture on cancer epidemiology and prevention. Cancer Res. 1992, 52, 6735-6740. [PubMed]

5. Giroux, V.; Rustgi, A.K. Metaplasia: Tissue injury adaptation and a precursor to the dysplasia-cancer sequence. Nat. Rev. Cancer 2017, 17, 594-604. [CrossRef] [PubMed]

6. Kimura, K.; Satoh, K.; Ido, K.; Taniguchi, Y.; Takimoto, T.; Takemoto, T. Gastritis in the Japanese stomach. Scand. J. Gastroenterol. 1996, 31, 17-20. [CrossRef]

7. Shichijo, S.; Hirata, Y.; Sakitani, K.; Yamamoto, S.; Serizawa, T.; Niikura, R.; Watabe, H.; Yoshida, S.; Yamada, A.; Yamaji, Y.; et al. Distribution of intestinal metaplasia as a predictor of gastric cancer development. J. Gastroenterol. Hepatol. 2015, 30, 1260-1264. [CrossRef] [PubMed]

8. Rugge, M.; de Boni, M.; Pennelli, G.; de Bona, M.; Giacomelli, L.; Fassan, M.; Basso, D.; Plebani, M.; Graham, D.Y. Gastritis olga-staging and gastric cancer risk: A twelve-year clinico-pathological follow-up study. Aliment. Pharmacol. Ther. 2010, 31, 1104-1111. [CrossRef] [PubMed]

9. Capelle, L.G.; de Vries, A.C.; Haringsma, J.; Ter Borg, F.; de Vries, R.A.; Bruno, M.J.; van Dekken, H.; Meijer, J.; van Grieken, N.C.; Kuipers, E.J. The staging of gastritis with the olga system by using intestinal metaplasia as an accurate alternative for atrophic gastritis. Gastrointest. Endosc. 2010, 71, 1150-1158. [CrossRef] [PubMed]

10. Kato, I.; Tominaga, S.; Ito, Y.; Kobayashi, S.; Yoshii, Y.; Matsuura, A.; Kameya, A.; Kano, T.; Ikari, A. A prospective study of atrophic gastritis and stomach cancer risk. Jpn. J. Cancer Res. 1992, 83, 1137-1142. [CrossRef] [PubMed]

11. Cassaro, M.; Rugge, M.; Gutierrez, O.; Leandro, G.; Graham, D.Y.; Genta, R.M. Topographic patterns of intestinal metaplasia and gastric cancer. Am. J. Gastroenterol. 2000, 95, 1431-1438. [CrossRef] [PubMed]

12. De Vries, A.C.; van Grieken, N.C.; Looman, C.W.; Casparie, M.K.; de Vries, E.; Meijer, G.A.; Kuipers, E.J. Gastric cancer risk in patients with premalignant gastric lesions: A nationwide cohort study in the Netherlands. Gastroenterology 2008, 134, 945-952. [CrossRef] [PubMed]

13. Sakitani, K.; Hirata, Y.; Watabe, H.; Yamada, A.; Sugimoto, T.; Yamaji, Y.; Yoshida, H.; Maeda, S.; Omata, M.; Koike, K. Gastric cancer risk according to the distribution of intestinal metaplasia and neutrophil infiltration. J. Gastroenterol. Hepatol. 2011, 26, 1570-1575. [CrossRef] [PubMed]

14. Lim, J.H.; Kim, N.; Lee, H.S.; Choe, G.; Jo, S.Y.; Chon, I.; Choi, C.; Yoon, H.; Shin, C.M.; Park, Y.S.; et al. Correlation between endoscopic and histological diagnoses of gastric intestinal metaplasia. Gut Liver 2013, 7 , 41-50. [CrossRef] [PubMed]

15. Shichijo, S.; Hirata, Y.; Niikura, R.; Hayakawa, Y.; Yamada, A.; Ushiku, T.; Fukayama, M.; Koike, K. Histological intestinal metaplasia and endoscopic atrophy are predictors of gastric cancer development after Helicobacter pylori eradication. Gastrointest. Endosc. 2016, 84, 618-624. [CrossRef] [PubMed]

16. Fukase, K.; Kato, M.; Kikuchi, S.; Inoue, K.; Uemura, N.; Okamoto, S.; Terao, S.; Amagai, K.; Hayashi, S.; Asaka, M. Effect of eradication of Helicobacter pylori on incidence of metachronous gastric carcinoma after endoscopic resection of early gastric cancer: An open-label, randomised controlled trial. Lancet 2008, 372, 392-397. [CrossRef]

17. Ogura, K.; Hirata, Y.; Yanai, A.; Shibata, W.; Ohmae, T.; Mitsuno, Y.; Maeda, S.; Watabe, H.; Yamaji, Y.; Okamoto, M.; et al. The effect of Helicobacter pylori eradication on reducing the incidence of gastric cancer. J. Clin. Gastroenterol. 2008, 42, 279-283. [CrossRef] [PubMed]

18. Mera, R.M.; Bravo, L.E.; Camargo, M.C.; Bravo, J.C.; Delgado, A.G.; Romero-Gallo, J.; Yepez, M.C.; Realpe, J.L.; Schneider, B.G.; Morgan, D.R.; et al. Dynamics of Helicobacter pylori infection as a determinant of progression of gastric precancerous lesions: 16-year follow-up of an eradication trial. Gut 2017. [CrossRef] [PubMed]

19. Wang, J.; Xu, L.; Shi, R.; Huang, X.; Li, S.W.; Huang, Z.; Zhang, G. Gastric atrophy and intestinal metaplasia before and after Helicobacter pylori eradication: A meta-analysis. Digestion 2011, 83, 253-260. [CrossRef] [PubMed]

20. Kodama, M.; Murakami, K.; Okimoto, T.; Sato, R.; Uchida, M.; Abe, T.; Shiota, S.; Nakagawa, Y.; Mizukami, K.; Fujioka, T. Ten-year prospective follow-up of histological changes at five points on the gastric mucosa as 
recommended by the updated sydney system after Helicobacter pylori eradication. J. Gastroenterol. 2012, 47, 394-403. [CrossRef] [PubMed]

21. Correa, P.; Fontham, E.T.; Bravo, J.C.; Bravo, L.E.; Ruiz, B.; Zarama, G.; Realpe, J.L.; Malcom, G.T.; Li, D.; Johnson, W.D.; et al. Chemoprevention of gastric dysplasia: Randomized trial of antioxidant supplements and anti-Helicobacter pylori therapy. J. Natl. Cancer Inst. 2000, 92, 1881-1888. [CrossRef] [PubMed]

22. Zullo, A.; Rinaldi, V.; Hassan, C.; Diana, F.; Winn, S.; Castagna, G.; Attili, A.F. Ascorbic acid and intestinal metaplasia in the stomach: A prospective, randomized study. Aliment. Pharmacol. Ther. 2000, 14, 1303-1309. [CrossRef] [PubMed]

23. Kong, Y.J.; Yi, H.G.; Dai, J.C.; Wei, M.X. Histological changes of gastric mucosa after Helicobacter pylori eradication: A systematic review and meta-analysis. World J. Gastroenterol. 2014, 20, 5903-5911. [CrossRef] [PubMed]

24. Heilmann, K.L.; Hopker, W.W. Loss of differentiation in intestinal metaplasia in cancerous stomachs. A comparative morphologic study. Pathol. Res. Pract. 1979, 164, 249-258. [CrossRef]

25. Filipe, M.I.; Munoz, N.; Matko, I.; Kato, I.; Pompe-Kirn, V.; Jutersek, A.; Teuchmann, S.; Benz, M.; Prijon, T. Intestinal metaplasia types and the risk of gastric cancer: A cohort study in Slovenia. Int. J. Cancer 1994, 57, 324-329. [CrossRef] [PubMed]

26. Shiotani, A.; Iishi, H.; Ishiguro, S.; Tatsuta, M.; Nakae, Y.; Merchant, J.L. Epithelial cell turnover in relation to ongoing damage of the gastric mucosa in patients with early gastric cancer: Increase of cell proliferation in paramalignant lesions. J. Gastroenterol. 2005, 40, 337-344. [CrossRef] [PubMed]

27. Pittayanon, R.; Rerknimitr, R.; Klaikaew, N.; Sanpavat, A.; Chaithongrat, S.; Mahachai, V.; Kullavanijaya, P.; Barkun, A. The risk of gastric cancer in patients with gastric intestinal metaplasia in 5-year follow-up. Aliment. Pharmacol. Ther. 2017, 46, 40-45. [CrossRef] [PubMed]

28. Gonzalez, C.A.; Sanz-Anquela, J.M.; Companioni, O.; Bonet, C.; Berdasco, M.; Lopez, C.; Mendoza, J.; Martin-Arranz, M.D.; Rey, E.; Poves, E.; et al. Incomplete type of intestinal metaplasia has the highest risk to progress to gastric cancer: Results of the spanish follow-up multicenter study. J. Gastroenterol. Hepatol. 2016, 31, 953-958. [CrossRef] [PubMed]

29. Wang, X.T.; Wei, W.Y.; Kong, F.B.; Lian, C.; Luo, W.; Xiao, Q.; Xie, Y.B. Prognostic significance of Cdx2 immunohistochemical expression in gastric cancer: A meta-analysis of published literatures. J. Exp. Clin. Cancer Res. 2012, 31, 98. [CrossRef] [PubMed]

30. Correa, P.; Piazuelo, M.B.; Wilson, K.T. Pathology of gastric intestinal metaplasia: Clinical implications. Am. J. Gastroenterol. 2010, 105, 493-498. [CrossRef] [PubMed]

31. Rokkas, T.; Filipe, M.I.; Sladen, G.E. Detection of an increased incidence of early gastric cancer in patients with intestinal metaplasia type III who are closely followed up. Gut 1991, 32, 1110-1113. [CrossRef] [PubMed]

32. Gutierrez-Gonzalez, L.; Graham, T.A.; Rodriguez-Justo, M.; Leedham, S.J.; Novelli, M.R.; Gay, L.J.; Ventayol-Garcia, T.; Green, A.; Mitchell, I.; Stoker, D.L.; et al. The clonal origins of dysplasia from intestinal metaplasia in the human stomach. Gastroenterology 2011, 140, 1251-1260. [CrossRef] [PubMed]

33. Ochiai, A.; Yamauchi, Y.; Hirohashi, S. P53 mutations in the non-neoplastic mucosa of the human stomach showing intestinal metaplasia. Int. J. Cancer 1996, 69, 28-33. [CrossRef]

34. Hayakawa, Y.; Sethi, N.; Sepulveda, A.R.; Bass, A.J.; Wang, T.C. Oesophageal adenocarcinoma and gastric cancer: Should we mind the gap? Nat. Rev. Cancer 2016, 16, 305-318. [CrossRef] [PubMed]

35. Leung, W.K.; Yu, J.; To, K.F.; Go, M.Y.; Ma, P.K.; Chan, F.K.; Sung, J.J. Apoptosis and proliferation in Helicobacter pylori-associated gastric intestinal metaplasia. Aliment. Pharmacol. Ther. 2001, 15, 1467-1472. [CrossRef] [PubMed]

36. Hayakawa, Y.; Fox, J.G.; Gonda, T.; Worthley, D.L.; Muthupalani, S.; Wang, T.C. Mouse models of gastric cancer. Cancers 2013, 5, 92-130. [CrossRef] [PubMed]

37. Wang, T.C.; Goldenring, J.R.; Dangler, C.; Ito, S.; Mueller, A.; Jeon, W.K.; Koh, T.J.; Fox, J.G. Mice lacking secretory phospholipase A2 show altered apoptosis and differentiation with helicobacter felis infection. Gastroenterology 1998, 114, 675-689. [CrossRef]

38. Wang, T.C.; Dangler, C.A.; Chen, D.; Goldenring, J.R.; Koh, T.; Raychowdhury, R.; Coffey, R.J.; Ito, S.; Varro, A.; Dockray, G.J.; et al. Synergistic interaction between hypergastrinemia and helicobacter infection in a mouse model of gastric cancer. Gastroenterology 2000, 118, 36-47. [CrossRef]

39. Roth, K.A.; Kapadia, S.B.; Martin, S.M.; Lorenz, R.G. Cellular immune responses are essential for the development of helicobacter felis-associated gastric pathology. J. Immunol. 1999, 163, 1490-1497. [PubMed] 
40. Lee, Y.; Urbanska, A.M.; Hayakawa, Y.; Wang, H.; Au, A.S.; Luna, A.M.; Chang, W.; Jin, G.; Bhagat, G.; Abrams, J.A.; et al. Gastrin stimulates a cholecystokinin-2-receptor-expressing cardia progenitor cell and promotes progression of Barrett's-like esophagus. Oncotarget 2017, 8, 203-214. [CrossRef] [PubMed]

41. Takaishi, S.; Tu, S.; Dubeykovskaya, Z.A.; Whary, M.T.; Muthupalani, S.; Rickman, B.H.; Rogers, A.B.; Lertkowit, N.; Varro, A.; Fox, J.G.; et al. Gastrin is an essential cofactor for helicobacter-associated gastric corpus carcinogenesis in C57BL/6 mice. Am. J. Pathol. 2009, 175, 365-375. [CrossRef] [PubMed]

42. Hayakawa, Y.; Chang, W.; Jin, G.; Wang, T.C. Gastrin and upper GI cancers. Curr. Opin. Pharmacol. 2016, 31, 31-37. [CrossRef] [PubMed]

43. Hayakawa, Y.; Jin, G.; Wang, H.; Chen, X.; Westphalen, C.B.; Asfaha, S.; Renz, B.W.; Ariyama, H.; Dubeykovskaya, Z.A.; Takemoto, Y.; et al. CCK2R identifies and regulates gastric antral stem cell states and carcinogenesis. Gut 2015, 64, 544-553. [CrossRef] [PubMed]

44. Tomita, H.; Takaishi, S.; Menheniott, T.R.; Yang, X.; Shibata, W.; Jin, G.; Betz, K.S.; Kawakami, K.; Minamoto, T.; Tomasetto, C.; et al. Inhibition of gastric carcinogenesis by the hormone gastrin is mediated by suppression of TFF1 epigenetic silencing. Gastroenterology 2011, 140, 879-891. [CrossRef] [PubMed]

45. Soutto, M.; Belkhiri, A.; Piazuelo, M.B.; Schneider, B.G.; Peng, D.; Jiang, A.; Washington, M.K.; Kokoye, Y.; Crowe, S.E.; Zaika, A.; et al. Loss of TFF1 is associated with activation of NF-kB-mediated inflammation and gastric neoplasia in mice and humans. J. Clin. Investig. 2011, 121, 1753-1767. [CrossRef] [PubMed]

46. Lee, A.; O’Rourke, J.; de Ungria, M.C.; Robertson, B.; Daskalopoulos, G.; Dixon, M.F. A standardized mouse model of Helicobacter pylori infection: Introducing the sydney strain. Gastroenterology 1997, 112, 1386-1397. [CrossRef]

47. Arnold, I.C.; Lee, J.Y.; Amieva, M.R.; Roers, A.; Flavell, R.A.; Sparwasser, T.; Muller, A. Tolerance rather than immunity protects from Helicobacter pylori-induced gastric preneoplasia. Gastroenterology 2011, 140, 199-209. [CrossRef] [PubMed]

48. Serizawa, T.; Hirata, Y.; Hayakawa, Y.; Suzuki, N.; Sakitani, K.; Hikiba, Y.; Ihara, S.; Kinoshita, H.; Nakagawa, H.; Tateishi, K.; et al. Gastric metaplasia induced by Helicobacter pylori is associated with enhanced SOX9 expression via interleukin-1 signaling. Infect. Immun. 2015, 84, 562-572. [CrossRef] [PubMed]

49. Sayi, A.; Kohler, E.; Toller, I.M.; Flavell, R.A.; Müller, W.; Roers, A.; Müller, A. TLR-2-activated b cells suppress helicobacter-induced preneoplastic gastric immunopathology by inducing $\mathrm{T}$ regulatory-1 cells. J. Immunol. 2011, 186, 878-890. [CrossRef] [PubMed]

50. Banerjee, A.; Thamphiwatana, S.; Carmona, E.M.; Rickman, B.; Doran, K.S.; Obonyo, M. Deficiency of the myeloid differentiation primary response molecule MyD88 leads to an early and rapid development of helicobacter-induced gastric malignancy. Infect. Immun. 2014, 82, 356-363. [CrossRef] [PubMed]

51. Ericksen, R.E.; Rose, S.; Westphalen, C.B.; Shibata, W.; Muthupalani, S.; Tailor, Y.; Friedman, R.A.; Han, W.; Fox, J.G.; Ferrante, A.W., Jr.; et al. Obesity accelerates helicobacter felis-induced gastric carcinogenesis by enhancing immature myeloid cell trafficking and TH17 response. Gut 2014, 63, 385-394. [CrossRef] [PubMed]

52. Lofgren, J.L.; Whary, M.T.; Ge, Z.; Muthupalani, S.; Taylor, N.S.; Mobley, M.; Potter, A.; Varro, A.; Eibach, D.; Suerbaum, S.; et al. Lack of commensal flora in Helicobacter pylori-infected INS-GAS mice reduces gastritis and delays intraepithelial neoplasia. Gastroenterology 2011, 140, 210-220. [CrossRef] [PubMed]

53. Tu, S.; Bhagat, G.; Cui, G.; Takaishi, S.; Kurt-Jones, E.A.; Rickman, B.; Betz, K.S.; Penz-Oesterreicher, M.; Bjorkdahl, O.; Fox, J.G.; et al. Overexpression of interleukin-1 $\beta$ induces gastric inflammation and cancer and mobilizes myeloid-derived suppressor cells in mice. Cancer Cell 2008, 14, 408-419. [CrossRef] [PubMed]

54. Syu, L.J.; El-Zaatari, M.; Eaton, K.A.; Liu, Z.; Tetarbe, M.; Keeley, T.M.; Pero, J.; Ferris, J.; Wilbert, D.; Kaatz, A.; et al. Transgenic expression of interferon- $\gamma$ in mouse stomach leads to inflammation, metaplasia, and dysplasia. Am. J. Pathol. 2012, 181, 2114-2125. [CrossRef] [PubMed] 
55. Shibata, W.; Ariyama, H.; Westphalen, C.B.; Worthley, D.L.; Muthupalani, S.; Asfaha, S.; Dubeykovskaya, Z.; Quante, M.; Fox, J.G.; Wang, T.C. Stromal cell-derived factor-1 overexpression induces gastric dysplasia through expansion of stromal myofibroblasts and epithelial progenitors. Gut 2013, 62, 192-200. [CrossRef] [PubMed]

56. Asfaha, S.; Dubeykovskiy, A.N.; Tomita, H.; Yang, X.; Stokes, S.; Shibata, W.; Friedman, R.A.; Ariyama, H.; Dubeykovskaya, Z.A.; Muthupalani, S.; et al. Mice that express human interleukin-8 have increased mobilization of immature myeloid cells, which exacerbates inflammation and accelerates colon carcinogenesis. Gastroenterology 2013, 144, 155-166. [CrossRef] [PubMed]

57. Buzzelli, J.N.; Chalinor, H.V.; Pavlic, D.I.; Sutton, P.; Menheniott, T.R.; Giraud, A.S.; Judd, L.M. IL33 is a stomach alarmin that initiates a skewed TH2 response to injury and infection. Cell. Mol. Gastroenterol. Hepatol. 2015, 1, 203-221. [CrossRef] [PubMed]

58. Fox, J.G.; Rogers, A.B.; Whary, M.T.; Ge, Z.; Ohtani, M.; Jones, E.K.; Wang, T.C. Accelerated progression of gastritis to dysplasia in the pyloric antrum of TFF2 ${ }^{-/}$C57BL6 $\times$Sv129 Helicobacter pylori-infected mice. Am. J. Pathol. 2007, 171, 1520-1528. [CrossRef] [PubMed]

59. Hayakawa, Y.; Fox, J.G.; Wang, T.C. Isthmus stem cells are the origins of metaplasia in the gastric corpus. Cell. Mol. Gastroenterol. Hepatol. 2017, 4, 89-94. [CrossRef] [PubMed]

60. Schmidt, P.H.; Lee, J.R.; Joshi, V.; Playford, R.J.; Poulsom, R.; Wright, N.A.; Goldenring, J.R. Identification of a metaplastic cell lineage associated with human gastric adenocarcinoma. Lab. Investig. 1999, 79, 639-646. [PubMed]

61. Goldenring, J.R.; Nam, K.T.; Wang, T.C.; Mills, J.C.; Wright, N.A. Spasmolytic polypeptide-expressing metaplasia and intestinal metaplasia: Time for reevaluation of metaplasias and the origins of gastric cancer. Gastroenterology 2010, 138, 2207-2210. [CrossRef] [PubMed]

62. Peterson, A.J.; Menheniott, T.R.; O'Connor, L.; Walduck, A.K.; Fox, J.G.; Kawakami, K.; Minamoto, T.; Ong, E.K.; Wang, T.C.; Judd, L.M.; et al. Helicobacter pylori infection promotes methylation and silencing of trefoil factor 2, leading to gastric tumor development in mice and humans. Gastroenterology 2010, 139, 2005-2017. [CrossRef] [PubMed]

63. Silberg, D.G.; Sullivan, J.; Kang, E.; Swain, G.P.; Moffett, J.; Sund, N.J.; Sackett, S.D.; Kaestner, K.H. Cdx2 ectopic expression induces gastric intestinal metaplasia in transgenic mice. Gastroenterology 2002, 122, 689-696. [CrossRef] [PubMed]

64. Mutoh, H.; Hakamata, Y.; Sato, K.; Eda, A.; Yanaka, I.; Honda, S.; Osawa, H.; Kaneko, Y.; Sugano, K. Conversion of gastric mucosa to intestinal metaplasia in cdx2-expressing transgenic mice. Biochem. Biophys. Res. Commun. 2002, 294, 470-479. [CrossRef]

65. Mutoh, H.; Sakurai, S.; Satoh, K.; Osawa, H.; Hakamata, Y.; Takeuchi, T.; Sugano, K. Cdx1 induced intestinal metaplasia in the transgenic mouse stomach: Comparative study with Cdx2 transgenic mice. Gut 2004, 53, 1416-1423. [CrossRef] [PubMed]

66. Mutoh, H.; Sakurai, S.; Satoh, K.; Tamada, K.; Kita, H.; Osawa, H.; Tomiyama, T.; Sato, Y.; Yamamoto, H.; Isoda, N.; et al. Development of gastric carcinoma from intestinal metaplasia in Cdx2-transgenic mice. Cancer Res. 2004, 64, 7740-7747. [CrossRef] [PubMed]

67. Okumura, T.; Ericksen, R.E.; Takaishi, S.; Wang, S.S.; Dubeykovskiy, Z.; Shibata, W.; Betz, K.S.; Muthupalani, S.; Rogers, A.B.; Fox, J.G.; et al. K-ras mutation targeted to gastric tissue progenitor cells results in chronic inflammation, an altered microenvironment, and progression to intraepithelial neoplasia. Cancer Res. 2010, 70, 8435-8445. [CrossRef] [PubMed]

68. Ray, K.C.; Bell, K.M.; Yan, J.; Gu, G.; Chung, C.H.; Washington, M.K.; Means, A.L. Epithelial tissues have varying degrees of susceptibility to kras ${ }^{\mathrm{G} 12 \mathrm{D}}$-initiated tumorigenesis in a mouse model. PLoS ONE 2011, 6, e16786. [CrossRef] [PubMed]

69. Matkar, S.S.; Durham, A.; Brice, A.; Wang, T.C.; Rustgi, A.K.; Hua, X. Systemic activation of K-ras rapidly induces gastric hyperplasia and metaplasia in mice. Am. J. Cancer Res. 2011, 1, 432-445. [PubMed]

70. Hayakawa, Y.; Ariyama, H.; Stancikova, J.; Sakitani, K.; Asfaha, S.; Renz, B.W.; Dubeykovskaya, Z.A.; Shibata, W.; Wang, H.; Westphalen, C.B.; et al. Mist1 expressing gastric stem cells maintain the normal and neoplastic gastric epithelium and are supported by a perivascular stem cell niche. Cancer Cell 2015, 28, 800-814. [CrossRef] [PubMed] 
71. Choi, E.; Hendley, A.M.; Bailey, J.M.; Leach, S.D.; Goldenring, J.R. Expression of activated ras in gastric chief cells of mice leads to the full spectrum of metaplastic lineage transitions. Gastroenterology 2016, 150, 918-930. [CrossRef] [PubMed]

72. Thiem, S.; Eissmann, M.F.; Elzer, J.; Jonas, A.; Putoczki, T.L.; Poh, A.; Nguyen, P.; Preaudet, A.; Flanagan, D.; Waring, P.; et al. Stomach-specific activation of oncogenic kRAS and STAT3-dependent inflammation cooperatively promote gastric tumorigenesis in a preclinical model. Cancer Res. 2016, 76, 2277-2287. [CrossRef] [PubMed]

73. Matsuo, J.; Kimura, S.; Yamamura, A.; Koh, C.P.; Hossain, M.Z.; Heng, D.L.; Kohu, K.; Chih-Cheng Voon, D.; Hiai, H.; Unno, M.; et al. Identification of stem cells in the epithelium of the stomach corpus and antrum of mice. Gastroenterology 2016, 152, 218-231. [CrossRef] [PubMed]

74. Leushacke, M.; Tan, S.H.; Wong, A.; Swathi, Y.; Hajamohideen, A.; Tan, L.T.; Goh, J.; Wong, E.; Denil, S.; Murakami, K.; et al. Lgr5-expressing chief cells drive epithelial regeneration and cancer in the oxyntic stomach. Nat. Cell. Biol. 2017, 19, 774-786. [CrossRef] [PubMed]

75. Goldenring, J.R.; Ray, G.S.; Soroka, C.J.; Smith, J.; Modlin, I.M.; Meise, K.S.; Coffey, R.J., Jr. Overexpression of transforming growth factor- $\alpha$ alters differentiation of gastric cell lineages. Dig. Dis. Sci. 1996, 41, 773-784. [CrossRef] [PubMed]

76. Takagi, H.; Fukusato, T.; Kawaharada, U.; Kuboyama, S.; Merlino, G.; Tsutsumi, Y. Histochemical analysis of hyperplastic stomach of TGF- $\alpha$ transgenic mice. Dig. Dis. Sci. 1997, 42, 91-98. [CrossRef] [PubMed]

77. Nam, K.T.; Lee, H.J.; Mok, H.; Romero-Gallo, J.; Crowe, J.E., Jr.; Peek, R.M., Jr.; Goldenring, J.R. Amphiregulin-deficient mice develop spasmolytic polypeptide expressing metaplasia and intestinal metaplasia. Gastroenterology 2009, 136, 1288-1296. [CrossRef] [PubMed]

78. Nam, K.T.; O’Neal, R.; Lee, Y.S.; Lee, Y.C.; Coffey, R.J.; Goldenring, J.R. Gastric tumor development in Smad3-deficient mice initiates from forestomach/glandular transition zone along the lesser curvature. Lab. Investig. 2012, 92, 883-895. [CrossRef] [PubMed]

79. Shinohara, M.; Mao, M.; Keeley, T.M.; El-Zaatari, M.; Lee, H.J.; Eaton, K.A.; Samuelson, L.C.; Merchant, J.L.; Goldenring, J.R.; Todisco, A. Bone morphogenetic protein signaling regulates gastric epithelial cell development and proliferation in mice. Gastroenterology 2010, 139, 2050-2060. [CrossRef] [PubMed]

80. Heijmans, J.; van den Brink, G.R. Morphogens and the parietal cell: Shaping up acid secretion. Gastroenterology 2010, 139, 1830-1833. [CrossRef] [PubMed]

81. Bleuming, S.A.; He, X.C.; Kodach, L.L.; Hardwick, J.C.; Koopman, F.A.; Ten Kate, F.J.; van Deventer, S.J.; Hommes, D.W.; Peppelenbosch, M.P.; Offerhaus, G.J.; et al. Bone morphogenetic protein signaling suppresses tumorigenesis at gastric epithelial transition zones in mice. Cancer Res. 2007, 67, 8149-8155. [CrossRef] [PubMed]

82. Nomura, S.; Yamaguchi, H.; Ogawa, M.; Wang, T.C.; Lee, J.R.; Goldenring, J.R. Alterations in gastric mucosal lineages induced by acute oxyntic atrophy in wild-type and gastrin-deficient mice. Am. J. Physiol. Gastrointest. Liver Physiol. 2005, 288, G362-375. [CrossRef] [PubMed]

83. Nam, K.T.; Lee, H.J.; Sousa, J.F.; Weis, V.G.; O’Neal, R.L.; Finke, P.E.; Romero-Gallo, J.; Shi, G.; Mills, J.C.; Peek, R.M., Jr.; et al. Mature chief cells are cryptic progenitors for metaplasia in the stomach. Gastroenterology 2010, 139, 2028-2037 e2029. [CrossRef] [PubMed]

84. Huh, W.J.; Khurana, S.S.; Geahlen, J.H.; Kohli, K.; Waller, R.A.; Mills, J.C. Tamoxifen induces rapid, reversible atrophy, and metaplasia in mouse stomach. Gastroenterology 2012, 142, 21-24. [CrossRef] [PubMed]

85. Burclaff, J.; Osaki, L.H.; Liu, D.; Goldenring, J.R.; Mills, J.C. Targeted apoptosis of parietal cells is insufficient to induce metaplasia in stomach. Gastroenterology 2016, 152, 762-766. [CrossRef] [PubMed]

86. Petersen, C.P.; Weis, V.G.; Nam, K.T.; Sousa, J.F.; Fingleton, B.; Goldenring, J.R. Macrophages promote progression of spasmolytic polypeptide-expressing metaplasia after acute loss of parietal cells. Gastroenterology 2014, 146, 1727-1738. [CrossRef] [PubMed]

87. Petersen, C.P.; Meyer, A.R.; DeSalvo, C.; Choi, E.; Schlegel, C.; Petersen, A.; Engevik, A.C.; Prasad, N.; Levy, S.E.; Peebles, R.S.; et al. A signalling cascade of IL-33 to IL-13 regulates metaplasia in the mouse stomach. Gut 2017. [CrossRef] [PubMed]

88. Choi, E.; Lantz, T.L.; Vlacich, G.; Keeley, T.M.; Samuelson, L.C.; Coffey, R.J.; Goldenring, J.R.; Powell, A.E. Lrig1 ${ }^{+}$gastric isthmal progenitor cells restore normal gastric lineage cells during damage recovery in adult mouse stomach. Gut 2017. [CrossRef] [PubMed] 
89. Menheniott, T.R.; O'Connor, L.; Chionh, Y.T.; Dabritz, J.; Scurr, M.; Rollo, B.N.; Ng, G.Z.; Jacobs, S.; Catubig, A.; Kurklu, B.; et al. Loss of gastrokine-2 drives premalignant gastric inflammation and tumor progression. J. Clin. Investig. 2016, 126, 1383-1400. [CrossRef] [PubMed]

90. Hayakawa, Y.; Wang, T.C. Isthmus progenitors, not chief cells, are the likely origin of metaplasia in eR1-CreERT; LSL-Kras G12D mice. Gastroenterology 2017, 152, 2078-2079. [CrossRef] [PubMed]

91. Hayakawa, Y.; Fox, J.G.; Wang, T.C. The origins of gastric cancer from gastric stem cells: Lessons from mouse models. Cell. Mol. Gastroenterol. Hepatol. 2017, 3, 331-338. [CrossRef] [PubMed]

92. Mills, J.C.; Goldenring, J.R. Metaplasia in the stomach arises from gastric chief cells. CMGH 2017, 4, 85-88. [CrossRef] [PubMed]

93. Spechler, S.J.; Merchant, J.L.; Wang, T.C.; Chandrasoma, P.; Fox, J.G.; Genta, R.M.; Goldenring, J.R.; Hayakawa, Y.; Kuipers, E.J.; Lund, P.K.; et al. A summary of the 2016 james W. Freston conference of the american gastroenterological association: Intestinal metaplasia in the esophagus and stomach: Origins, differences, similarities and significance. Gastroenterology 2017, 153, e6-e13. [CrossRef] [PubMed]

94. Nam, K.T.; O’Neal, R.L.; Coffey, R.J.; Finke, P.E.; Barker, N.; Goldenring, J.R. Spasmolytic polypeptide-expressing metaplasia (SPEM) in the gastric oxyntic mucosa does not arise from Lgr5-expressing cells. Gut 2012, 61, 1678-1685. [CrossRef] [PubMed]

95. Westphalen, C.B.; Asfaha, S.; Hayakawa, Y.; Takemoto, Y.; Lukin, D.J.; Nuber, A.H.; Brandtner, A.; Setlik, W.; Remotti, H.; Muley, A.; et al. Long-lived intestinal tuft cells serve as colon cancer-initiating cells. J. Clin. Investig. 2014, 124, 1283-1295. [CrossRef] [PubMed]

96. Liu, J.; Willet, S.G.; Bankaitis, E.D.; Xu, Y.; Wright, C.V.; Gu, G. Non-parallel recombination limits cre-loxP-based reporters as precise indicators of conditional genetic manipulation. Genesis 2013, 51, 436-442. [CrossRef] [PubMed]

97. Polk, D.B.; Peek, R.M., Jr. Helicobacter pylori: Gastric cancer and beyond. Nat. Rev. Cancer 2010, 10, 403-414. [CrossRef] [PubMed]

98. Backert, S.; Naumann, M. What a disorder: Proinflammatory signaling pathways induced by Helicobacter pylori. Trends Microbiol. 2010, 18, 479-486. [CrossRef] [PubMed]

99. Backert, S.; Clyne, M.; Tegtmeyer, N. Molecular mechanisms of gastric epithelial cell adhesion and injection of CagA by Helicobacter pylori. Cell. Commun. Signal. 2011, 9, 28. [CrossRef] [PubMed]

100. Hatakeyama, M. Helicobacter pylori CagA and gastric cancer: A paradigm for hit-and-run carcinogenesis. Cell. Host Microbe 2014, 15, 306-316. [CrossRef] [PubMed]

101. Sue, S.; Shibata, W.; Maeda, S. Helicobacter pylori-induced signaling pathways contribute to intestinal metaplasia and gastric carcinogenesis. Biomed. Res. Int. 2015, 2015, 737621. [CrossRef] [PubMed]

102. Amieva, M.; Peek, R.M., Jr. Pathobiology of Helicobacter pylori-induced gastric cancer. Gastroenterology 2016, 150, 64-78. [CrossRef] [PubMed]

103. Bartfeld, S.; Bayram, T.; van de Wetering, M.; Huch, M.; Begthel, H.; Kujala, P.; Vries, R.; Peters, P.J.; Clevers, H. In vitro expansion of human gastric epithelial stem cells and their responses to bacterial infection. Gastroenterology 2015, 148, 126-136. [CrossRef] [PubMed]

104. Blaser, M.J.; Perez-Perez, G.I.; Kleanthous, H.; Cover, T.L.; Peek, R.M.; Chyou, P.H.; Stemmermann, G.N.; Nomura, A. Infection with Helicobacter pylori strains possessing CagA is associated with an increased risk of developing adenocarcinoma of the stomach. Cancer Res. 1995, 55, 2111-2115. [PubMed]

105. Ogura, K.; Maeda, S.; Nakao, M.; Watanabe, T.; Tada, M.; Kyutoku, T.; Yoshida, H.; Shiratori, Y.; Omata, M. Virulence factors of Helicobacter pylori responsible for gastric diseases in mongolian gerbil. J. Exp. Med. 2000, 192, 1601-1610. [CrossRef] [PubMed]

106. Censini, S.; Lange, C.; Xiang, Z.; Crabtree, J.E.; Ghiara, P.; Borodovsky, M.; Rappuoli, R.; Covacci, A. $c a g$, A pathogenicity island of Helicobacter pylori, encodes type I-specific and disease-associated virulence factors. Proc. Natl. Acad. Sci. USA 1996, 93, 14648-14653. [CrossRef] [PubMed]

107. Backert, S.; Ziska, E.; Brinkmann, V.; Zimny-Arndt, U.; Fauconnier, A.; Jungblut, P.R.; Naumann, M.; Meyer, T.F. Translocation of the Helicobacter pylori CagA protein in gastric epithelial cells by a type iv secretion apparatus. Cell. Microbiol 2000, 2, 155-164. [CrossRef] [PubMed]

108. Odenbreit, S.; Puls, J.; Sedlmaier, B.; Gerland, E.; Fischer, W.; Haas, R. Translocation of Helicobacter pylori CagA into gastric epithelial cells by type IV secretion. Science 2000, 287, 1497-1500. [CrossRef] [PubMed] 
109. Hirata, Y.; Maeda, S.; Mitsuno, Y.; Tateishi, K.; Yanai, A.; Akanuma, M.; Yoshida, H.; Kawabe, T.; Shiratori, Y.; Omata, M. Helicobacter pylori CagA protein activates serum response element-driven transcription independently of tyrosine phosphorylation. Gastroenterology 2002, 123, 1962-1971. [CrossRef] [PubMed]

110. Mitsuno, Y.; Yoshida, H.; Maeda, S.; Ogura, K.; Hirata, Y.; Kawabe, T.; Shiratori, Y.; Omata, M. Helicobacter pylori induced transactivation of SRE and AP-1 through the ERK signalling pathway in gastric cancer cells. Gut 2001, 49, 18-22. [CrossRef] [PubMed]

111. Higashi, H.; Tsutsumi, R.; Muto, S.; Sugiyama, T.; Azuma, T.; Asaka, M.; Hatakeyama, M. SHP-2 tyrosine phosphatase as an intracellular target of Helicobacter pylori CagA protein. Science 2002, 295, 683-686. [CrossRef] [PubMed]

112. Saito, Y.; Murata-Kamiya, N.; Hirayama, T.; Ohba, Y.; Hatakeyama, M. Conversion of Helicobacter pylori CagA from senescence inducer to oncogenic driver through polarity-dependent regulation of p21. J. Exp. Med. 2010, 207, 2157-2174. [CrossRef] [PubMed]

113. Hirata, Y.; Maeda, S.; Mitsuno, Y.; Akanuma, M.; Yamaji, Y.; Ogura, K.; Yoshida, H.; Shiratori, Y.; Omata, M. Helicobacter pylori activates the cyclin D1 gene through mitogen-activated protein kinase pathway in gastric cancer cells. Infect. Immun. 2001, 69, 3965-3971. [CrossRef] [PubMed]

114. Ohnishi, N.; Yuasa, H.; Tanaka, S.; Sawa, H.; Miura, M.; Matsui, A.; Higashi, H.; Musashi, M.; Iwabuchi, K.; Suzuki, M.; et al. Transgenic expression of Helicobacter pylori CagA induces gastrointestinal and hematopoietic neoplasms in mouse. Proc. Natl. Acad. Sci. USA 2008, 105, 1003-1008. [CrossRef] [PubMed]

115. Basu, S.; Pathak, S.K.; Chatterjee, G.; Pathak, S.; Basu, J.; Kundu, M. Helicobacter pylori protein HP0175 transactivates epidermal growth factor receptor through TLR4 in gastric epithelial cells. J. Biol. Chem. 2008, 283, 32369-32376. [CrossRef] [PubMed]

116. Sierra, J.C.; Asim, M.; Verriere, T.G.; Piazuelo, M.B.; Suarez, G.; Romero-Gallo, J.; Delgado, A.G.; Wroblewski, L.E.; Barry, D.P.; Peek, R.M., Jr.; et al. Epidermal growth factor receptor inhibition downregulates Helicobacter pylori-induced epithelial inflammatory responses, DNA damage and gastric carcinogenesis. Gut 2017. [CrossRef] [PubMed]

117. Franco, A.T.; Israel, D.A.; Washington, M.K.; Krishna, U.; Fox, J.G.; Rogers, A.B.; Neish, A.S.; Collier-Hyams, L.; Perez-Perez, G.I.; Hatakeyama, M.; et al. Activation of beta-catenin by carcinogenic Helicobacter pylori. Proc. Natl. Acad. Sci. USA 2005, 102, 10646-10651. [CrossRef] [PubMed]

118. Murata-Kamiya, N.; Kurashima, Y.; Teishikata, Y.; Yamahashi, Y.; Saito, Y.; Higashi, H.; Aburatani, H.; Akiyama, T.; Peek, R.M., Jr.; Azuma, T.; et al. Helicobacter pylori CagA interacts with E-cadherin and deregulates the $\beta$-catenin signal that promotes intestinal transdifferentiation in gastric epithelial cells. Oncogene 2007, 26, 4617-4626. [CrossRef] [PubMed]

119. Bronte-Tinkew, D.M.; Terebiznik, M.; Franco, A.; Ang, M.; Ahn, D.; Mimuro, H.; Sasakawa, C.; Ropeleski, M.J.; Peek, R.M., Jr.; Jones, N.L. Helicobacter pylori cytotoxin-associated gene a activates the signal transducer and activator of transcription 3 pathway in vitro and in vivo. Cancer Res. 2009, 69, 632-639. [CrossRef] [PubMed]

120. Lee, I.O.; Kim, J.H.; Choi, Y.J.; Pillinger, M.H.; Kim, S.Y.; Blaser, M.J.; Lee, Y.C. Helicobacter pylori CagA phosphorylation status determines the GP130-activated SHP2/ERK and JAK/STAT signal transduction pathways in gastric epithelial cells. J. Biol. Chem. 2010, 285, 16042-16050. [CrossRef] [PubMed]

121. Hayakawa, Y.; Hirata, Y.; Kinoshita, H.; Sakitani, K.; Nakagawa, H.; Nakata, W.; Takahashi, R.; Sakamoto, K.; Maeda, S.; Koike, K. Differential roles of ASK1 and TAK1 in Helicobacter pylori-induced cellular responses. Infect. Immun. 2013, 81, 4551-4560. [CrossRef] [PubMed]

122. Segal, E.D.; Cha, J.; Lo, J.; Falkow, S.; Tompkins, L.S. Altered states: Involvement of phosphorylated CagA in the induction of host cellular growth changes by Helicobacter pylori. Proc. Natl. Acad. Sci. USA 1999, 96, 14559-14564. [CrossRef] [PubMed]

123. Amieva, M.R.; Vogelmann, R.; Covacci, A.; Tompkins, L.S.; Nelson, W.J.; Falkow, S. Disruption of the epithelial apical-junctional complex by Helicobacter pylori CagA. Science 2003, 300, 1430-1434. [CrossRef] [PubMed]

124. Saadat, I.; Higashi, H.; Obuse, C.; Umeda, M.; Murata-Kamiya, N.; Saito, Y.; Lu, H.; Ohnishi, N.; Azuma, T.; Suzuki, A.; et al. Helicobacter pylori CagA targets PAR1/MARK kinase to disrupt epithelial cell polarity. Nature 2007, 447, 330-333. [CrossRef] [PubMed] 
125. Hirata, Y.; Ohmae, T.; Shibata, W.; Maeda, S.; Ogura, K.; Yoshida, H.; Kawabe, T.; Omata, M. MyD88 and tnf receptor-associated factor 6 are critical signal transducers in Helicobacter pylori-infected human epithelial cells. J. Immunol 2006, 176, 3796-3803. [CrossRef] [PubMed]

126. Hayakawa, Y.; Hirata, Y.; Nakagawa, H.; Sakamoto, K.; Hikiba, Y.; Kinoshita, H.; Nakata, W.; Takahashi, R.; Tateishi, K.; Tada, M.; et al. Apoptosis signal-regulating kinase 1 and cyclin D1 compose a positive feedback loop contributing to tumor growth in gastric cancer. Proc. Natl. Acad. Sci. USA 2011, 108, 780-785. [CrossRef] [PubMed]

127. Hayakawa, Y.; Hirata, Y.; Sakitani, K.; Nakagawa, H.; Nakata, W.; Kinoshita, H.; Takahashi, R.; Takeda, K.; Ichijo, H.; Maeda, S.; et al. Apoptosis signal-regulating kinase-1 inhibitor as a potent therapeutic drug for the treatment of gastric cancer. Cancer Sci 2012, 103, 2181-2185. [CrossRef] [PubMed]

128. Shibata, W.; Maeda, S.; Hikiba, Y.; Yanai, A.; Sakamoto, K.; Nakagawa, H.; Ogura, K.; Karin, M.; Omata, M. $\mathrm{C}$-Jun NH2-terminal kinase 1 is a critical regulator for the development of gastric cancer in mice. Cancer Res. 2008, 68, 5031-5039. [CrossRef] [PubMed]

129. Kawahara, T.; Teshima, S.; Kuwano, Y.; Oka, A.; Kishi, K.; Rokutan, K. Helicobacter pylori lipopolysaccharide induces apoptosis of cultured guinea pig gastric mucosal cells. Am. J. Physiol. Gastrointest. Liver Physiol. 2001, 281, G726-734. [PubMed]

130. Keates, S.; Hitti, Y.S.; Upton, M.; Kelly, C.P. Helicobacter pylori infection activates NF-к B in gastric epithelial cells. Gastroenterology 1997, 113, 1099-1109. [CrossRef] [PubMed]

131. Maeda, S.; Akanuma, M.; Mitsuno, Y.; Hirata, Y.; Ogura, K.; Yoshida, H.; Shiratori, Y.; Omata, M. Distinct mechanism of Helicobacter pylori-mediated NF-K B activation between gastric cancer cells and monocytic cells. J. Biol. Chem. 2001, 276, 44856-44864. [CrossRef] [PubMed]

132. Brandt, S.; Kwok, T.; Hartig, R.; Konig, W.; Backert, S. Nf-kappab activation and potentiation of proinflammatory responses by the Helicobacter pylori CagA protein. Proc. Natl. Acad. Sci. USA 2005, 102, 9300-9305. [CrossRef] [PubMed]

133. Lamb, A.; Yang, X.D.; Tsang, Y.H.; Li, J.D.; Higashi, H.; Hatakeyama, M.; Peek, R.M.; Blanke, S.R.; Chen, L.F. Helicobacter pylori CagA activates NF- $\mathrm{KB}$ by targeting TAK1 for TRAF6-mediated Lys 63 ubiquitination. EMBO Rep. 2009, 10, 1242-1249. [CrossRef] [PubMed]

134. Nakata, W.; Hayakawa, Y.; Nakagawa, H.; Sakamoto, K.; Kinoshita, H.; Takahashi, R.; Hirata, Y.; Maeda, S.; Koike, K. Anti-tumor activity of the proteasome inhibitor bortezomib in gastric cancer. Int. J. Oncol. 2011, 39, 1529-1536. [PubMed]

135. Sakitani, K.; Hirata, Y.; Hayakawa, Y.; Serizawa, T.; Nakata, W.; Takahashi, R.; Kinoshita, H.; Sakamoto, K.; Nakagawa, H.; Akanuma, M.; et al. Role of interleukin-32 in Helicobacter pylori-induced gastric inflammation. Infect. Immun. 2012, 80, 3795-3803. [CrossRef] [PubMed]

136. Varro, A.; Noble, P.J.; Pritchard, D.M.; Kennedy, S.; Hart, C.A.; Dimaline, R.; Dockray, G.J. Helicobacter pylori induces plasminogen activator inhibitor 2 in gastric epithelial cells through nuclear factor- $\mathrm{KB}$ and RhoA: Implications for invasion and apoptosis. Cancer Res. 2004, 64, 1695-1702. [CrossRef] [PubMed]

137. Cancer Genome Atlas, N. Comprehensive genomic characterization of head and neck squamous cell carcinomas. Nature 2015, 517, 576-582.

138. Zhou, J.; Hayakawa, Y.; Wang, T.C.; Bass, A.J. RhoA mutations identified in diffuse gastric cancer. Cancer Cell 2014, 26, 9-11. [CrossRef] [PubMed]

139. Wang, K.; Yuen, S.T.; Xu, J.; Lee, S.P.; Yan, H.H.; Shi, S.T.; Siu, H.C.; Deng, S.; Chu, K.M.; Law, S.; et al. Whole-genome sequencing and comprehensive molecular profiling identify new driver mutations in gastric cancer. Nat. Genet. 2014, 46, 573-582. [CrossRef] [PubMed]

140. Kakiuchi, M.; Nishizawa, T.; Ueda, H.; Gotoh, K.; Tanaka, A.; Hayashi, A.; Yamamoto, S.; Tatsuno, K.; Katoh, H.; Watanabe, Y.; et al. Recurrent gain-of-function mutations of RhoA in diffuse-type gastric carcinoma. Nat. Genet. 2014, 46, 583-587. [CrossRef] [PubMed]

141. Hirata, Y.; Maeda, S.; Ohmae, T.; Shibata, W.; Yanai, A.; Ogura, K.; Yoshida, H.; Kawabe, T.; Omata, M. Helicobacter pylori induces IкB kinase $\alpha$ nuclear translocation and chemokine production in gastric epithelial cells. Infect. Immun. 2006, 74, 1452-1461. [CrossRef] [PubMed]

142. Maeda, S.; Yoshida, H.; Ogura, K.; Mitsuno, Y.; Hirata, Y.; Yamaji, Y.; Akanuma, M.; Shiratori, Y.; Omata, M. H. Pylori activates through a signaling pathway involving ikappab kinases, NF-KB-inducing kinase, TRAF2, and TRAF6 in gastric cancer cells. Gastroenterology 2000, 119, 97-108. [CrossRef] [PubMed] 
143. Shibata, W.; Hirata, Y.; Maeda, S.; Ogura, K.; Ohmae, T.; Yanai, A.; Mitsuno, Y.; Yamaji, Y.; Okamoto, M.; Yoshida, H.; et al. Caga protein secreted by the intact type IV secretion system leads to gastric epithelial inflammation in the mongolian gerbil model. J. Pathol. 2006, 210, 306-314. [CrossRef] [PubMed]

144. Torok, A.M.; Bouton, A.H.; Goldberg, J.B. Helicobacter pylori induces interleukin-8 secretion by toll-like receptor 2- and toll-like receptor 5-dependent and -independent pathways. Infect. Immun. 2005, 73, 1523-1531. [CrossRef] [PubMed]

145. Smith, M.F., Jr.; Mitchell, A.; Li, G.; Ding, S.; Fitzmaurice, A.M.; Ryan, K.; Crowe, S.; Goldberg, J.B. Toll-like receptor (TLR) 2 and TLR 5, but not TLR 4, are required for Helicobacter pylori-induced NF-KB activation and chemokine expression by epithelial cells. J. Biol. Chem. 2003, 278, 32552-32560. [CrossRef] [PubMed]

146. Viala, J.; Chaput, C.; Boneca, I.G.; Cardona, A.; Girardin, S.E.; Moran, A.P.; Athman, R.; Memet, S.; Huerre, M.R.; Coyle, A.J.; et al. Nod1 responds to peptidoglycan delivered by the Helicobacter pylori cag pathogenicity island. Nat. Immunol 2004, 5, 1166-1174. [CrossRef] [PubMed]

147. Shibata, W.; Takaishi, S.; Muthupalani, S.; Pritchard, D.M.; Whary, M.T.; Rogers, A.B.; Fox, J.G.; Betz, K.S.; Kaestner, K.H.; Karin, M.; et al. Conditional deletion of IKB-kinase- $\beta$ accelerates helicobacter-dependent gastric apoptosis, proliferation, and preneoplasia. Gastroenterology 2010, 138, 1022-1034. [CrossRef] [PubMed]

148. Sakamoto, K.; Hikiba, Y.; Nakagawa, H.; Hayakawa, Y.; Yanai, A.; Akanuma, M.; Ogura, K.; Hirata, Y.; Kaestner, K.H.; Omata, M.; et al. Inhibitor of $\kappa B$ kinase $\beta$ regulates gastric carcinogenesis via interleukin- $1 \alpha$ expression. Gastroenterology 2010, 139, 226-238 e226. [CrossRef] [PubMed]

149. Niwa, T.; Tsukamoto, T.; Toyoda, T.; Mori, A.; Tanaka, H.; Maekita, T.; Ichinose, M.; Tatematsu, M.; Ushijima, T. Inflammatory processes triggered by Helicobacter pylori infection cause aberrant DNA methylation in gastric epithelial cells. Cancer Res. 2010, 70, 1430-1440. [CrossRef] [PubMed]

150. O'Gorman, A.; Colleran, A.; Ryan, A.; Mann, J.; Egan, L.J. Regulation of NF-kB responses by epigenetic suppression of Ik $\alpha$ expression in HCT116 intestinal epithelial cells. Am. J. Physiol Gastrointest Liver Physiol 2010, 299, G96-G105. [CrossRef] [PubMed]

151. Houghton, J.; Stoicov, C.; Nomura, S.; Rogers, A.B.; Carlson, J.; Li, H.; Cai, X.; Fox, J.G.; Goldenring, J.R.; Wang, T.C. Gastric cancer originating from bone marrow-derived cells. Science 2004, 306, 1568-1571. [CrossRef] [PubMed]

152. Hayakawa, Y.; Sakitani, K.; Konishi, M.; Asfaha, S.; Niikura, R.; Tomita, H.; Renz, B.W.; Tailor, Y.; Macchini, M.; Middelhoff, M.; et al. Nerve growth factor promotes gastric tumorigenesis through aberrant cholinergic signaling. Cancer Cell 2017, 31, 21-34. [CrossRef] [PubMed]

153. Zhao, C.M.; Hayakawa, Y.; Kodama, Y.; Muthupalani, S.; Westphalen, C.B.; Andersen, G.T.; Flatberg, A.; Johannessen, H.; Friedman, R.A.; Renz, B.W.; et al. Denervation suppresses gastric tumorigenesis. Sci. Transl. Med. 2014. [CrossRef] [PubMed]

154. Rabben, H.L.; Zhao, C.M.; Hayakawa, Y.; Wang, T.C.; Chen, D. Vagotomy and gastric tumorigenesis. Curr. Neuropharmacol. 2016, 14, 967-972. [CrossRef] [PubMed]

155. Quante, M.; Tu, S.P.; Tomita, H.; Gonda, T.; Wang, S.S.; Takashi, S.; Baik, G.H.; Shibata, W.; Diprete, B.; Betz, K.S.; et al. Bone marrow-derived myofibroblasts contribute to the mesenchymal stem cell niche and promote tumor growth. Cancer Cell 2011, 19, 257-272. [CrossRef] [PubMed]

(C) 2017 by the authors. Licensee MDPI, Basel, Switzerland. This article is an open access article distributed under the terms and conditions of the Creative Commons Attribution (CC BY) license (http:/ / creativecommons.org/licenses/by/4.0/). 